\title{
Determination of trace and heavy metals in drinking water of Jhal Magsi district of Balochistan, Pakistan
}

\author{
Safia Mustafa ${ }^{1}$, Nizam Baloch ${ }^{1}$, Shafi Muhammad ${ }^{2 *}$, Yasmeen Malik ${ }^{3}$, \\ Tamoor Khan ${ }^{4}$, Murad Bibi ${ }^{5}$, Abdul Qadir ${ }^{6}$, Ghulam Razaque ${ }^{6}$ and \\ Iftikhar Ahmed Baloch ${ }^{7}$
}

1. Department of Chemistry, University of Balochistan, Quetta-Pakistan

2. Department of Pharmacognosy, Faculty of Pharmacy and Health Sciences, University of Balochistan, Quetta-

Pakistan

3. Department of Zoology, University of Balochistan, Quetta-Pakistan

4. Faculty of Agriculture Lasbela University of Agriculture, Water and Marine Sciences, Lasbela-Pakistan

5. Department Pharmacology, Faculty of Pharmacy and Health Sciences, University of Balochistan, Quetta-Pakistan

6. Department of Pharmaceutics, Faculty of Pharmacy and Health Sciences, University of Balochistan, Quetta-

Pakistan

7. Department of Botany, University of Balochistan, Quetta-Pakistan

*Corresponding author's email: Pharmacognosist59@yahoo.com

Citation

Safia Mustafa, Nizam Baloch, Shafi Muhammad, Yasmeen Malik, Tamoor Khan, Murad Bibi, Abdul Qadir, Ghulam Razaque, Iftikhar Ahmed Baloch Determination of trace and heavy metals in drinking water of Jhal Magsi district of Balochistan, Pakistan. Pure and Applied Biology. Vol. 6, Issue 1, pp9-17.

http://dx.doi.org/10.19045/bspab.2016.50161

\begin{tabular}{llll}
\hline \hline Received: 08/10/2016 & Revised: 06/12/2016 & Accepted: 12/12/2016 & Online First: 19/12/2016 \\
\hline \hline
\end{tabular}

\section{Abstract}

Water is essential component of life. Pure drinking water is a necessity for humans. Balochistan is the largest province of Pakistan. In Balochistan river and well water is mainly used for drinking and agriculture purposes. Current study was carried out to determine the concentration of trace and heavy metals in river (surface) and well water of Jhal Magsi district of Balochistan. Ten (10) samples were collected from each, river (surface) and well water. Physicochemical parameters (PH, Electrical conductivity, Total dissolved solids, Dissolved Oxygen, Turbidity and Color) were determined. Determination of trace and heavy metals i.e. Zinc $(\mathrm{Zn})$, Iron $(\mathrm{Fe})$, Manganese $(\mathrm{Mn})$, Copper $(\mathrm{Cu})$, Cadmium (Cd), Lead ( $\mathrm{Pb})$, Chromium $(\mathrm{Cr})$ and Nickel $(\mathrm{Ni})$ were carried out using Atomic absorption Spectrophotometer. Except 3 samples (RW3, RW5 and WW6), the physicochemical parameters were within the world health organization (WHO) and environmental protection agency Pakistan (EPA) limits. Concentration of $\mathrm{Zn}, \mathrm{Fe}, \mathrm{Mn}$ and $\mathrm{Cu}$ were below the WHO and EPA limits. Concentration of $\mathrm{Pb}$ and $\mathrm{Cd}$ were higher than the standards set by WHO and EPA. Cr and Ni were not detected in any samples. Current study is the first study carried out to determine the concentration of trace and heavy metals in drinking water of Jhal Magsi district of Balochistan.

Keywords: Heavy metals; Physiochemical parameters; Jhal Magsi; River water; Ground water

\section{Introduction}

Water is the most essential element for living organisms and it supports the life processes. Without water it would not have been possible to sustain life on earth [1]. Water pollution has become a very critical 
area of study worldwide because of its direct implications on the aquatic life and the human beings [2]. The pollution of surface water by heavy metals is a serious environmental problem. They are nondegradable and can accumulate through food chain. Though some metals like $\mathrm{Fe}, \mathrm{Cu}$ and $\mathrm{Zn}$ are essential micronutrients, they can be harmful to the physiology of the living organisms at higher concentrations [3-5].

Balochistan is the largest province of Pakistan [6] and around 54\% area under is surface water irrigation and the remaining $46 \%$ is under groundwater irrigation [7]. People in Jhal Magsi district of Balochistan mostly rely on agriculture. Where the major sources of water are rivers, streams and tube wells. Therefore, people live mostly near the flowing rivers and streams to get water for their drinking and for irrigation of land. Some areas of the Jhal Magsi are also irrigated with flood water [8].

Rivers and streams are polluted due to the impurities coming mostly from industries and mixing up with sewerage discharge. These impurities may flow into the lakes or water reservoirs which store water for drinking [9]. Among the inorganic contaminants of the river water, heavy metals are getting importance for their nondegradable nature and often accumulate through tropic level causing a deleterious biological effect [3]. In this regard current research work was carried out to determine concentration of different trace and heavy metals in water samples of Jhal Magsi district used by the people for drinking and agriculture purpose. Current study is first report on determination of trace and heavy metals in drinking and agriculture water of Jhal Magsi, Balochistan.

\section{Material and methods}

\section{Study area}

The present study was undertaken in different areas of district Jhal Magsi. Water samples were collected from different areas of Jhal Magsi district (Table 1). To avoid possibility of contamination the polythene bottles (Jiangyin Huangma china) were used for the collection of water samples and were labeled accurately.

Table 1. Name of sampling area with their symbols

\begin{tabular}{|c|c|c|c|}
\hline Symbols & Area of surface water & Symbols & Area of well water \\
\hline RW1 & Pir Chattal & WW1 & Goth Mousa khal \\
\hline RW2 & Shoran & WW2 & Ghala lower region \\
\hline RW3 & Mula & WW3 & Patri \\
\hline RW4 & Gandawah & WW4 & Ghala upper region \\
\hline RW5 & Kahri & WW5 & Goth dandoo \\
\hline RW6 & Gajan & WW6 & Kotroh \\
\hline RW7 & Sukleji, & WW7 & Kohnara \\
\hline RW8 & Badrah & WW8 & kohri \\
\hline RW9 & Kotra Khari & WW9 & Jaht \\
\hline RW10 & Fatihpur & WW10 & Bazdana \\
\hline \multicolumn{2}{|c|}{$\begin{array}{l}\text { Sampling } \\
\text { Samples of water were collected from } \\
\text { different sampling Sites (Table 1) in bottles } \\
\text { and transported to the Department of } \\
\text { Chemistry, University of Balochistan. } \\
\text { Physiochemical parameters of water } \\
\text { samples } \\
\text { Physiochemical parameters of water samples }\end{array}$} & \multicolumn{2}{|c|}{$\begin{array}{l}\text { were carried out by method described by } \\
\text { Joshi et al. [10]. These parameters include: } \\
\text { PH } \\
\text { PH was detected by using PH meter } \\
\text { (JANWAY } 3305 \text { UK). } \\
\text { Electrical conductivity (EC) } \\
\text { Electrical conductivity (EC) was detected by } \\
\text { using EC meter (JANWAY } 4510 \text { UK). } \\
\text { Total dissolved solids (TDS) }\end{array}$} \\
\hline
\end{tabular}


This test was done on TDS meter (HACH COISO USA).

Dissolved oxygen (DO)

$\mathrm{DO}_{2}$ meter (JANWAY $9500 \mathrm{UK}$ ) was used for detection of dissolved oxygen.

\section{Turbidity}

Turbidity was detected by using laboratory turbidity meter (HACH 2100p USA).

\section{Color}

Color is a qualitative characteristic of waste water. Color was detected by using laboratory turbidmeter (HACH 2100p USA).

\section{Sample preparation for heavy metal analysis \\ Sample preparation}

Samples of water were brought in laboratory and the process of digestion was carried out. The digestion was performed by addition of ten (10) $\mathrm{ml}$ sample into the five $(05) \mathrm{ml}$ of concentrated $\mathrm{HCl}$ and five (05) $\mathrm{ml}$ of concentrated $\mathrm{HNO}_{3}$. The solution was twirled gradually, then covered with help of watch glass, allowed for 1 hour at room temperature. The solution was heated by the help of hot plate, fumes of yellow color were released and the samples were turn out to be clear. The acidic solution after cooling was filtered by filter paper (Millipore filter $0.4 \mu$ ) and then deionized water was added to make the volume $100 \mathrm{ml}$ [11].

\section{Standard preparation}

Different prepared standards (1000 ppm) of each metals (Fisher Chemicals, U.K.) were diluted with deionized water. The compounds used for analytical determination were ultra-pure [12].

\section{Analysis}

Atomic Absorption Spectrometer (PerkinAnalyst 800 JAPAN) was used for analysis of Zinc ( $\mathrm{Zn})$, Iron (Fe), Manganese $(\mathrm{Mn})$, Copper $(\mathrm{Cu})$, Cadmium $(\mathrm{Cd})$, Lead $(\mathrm{Pb})$, Chromium (Cr) and Nickel (Ni) [13-15].

\section{Results}

\section{Physiochemical parameters}

\section{River (surface) water}

In all samples the $\mathrm{pH}$ ranged from 7.31 to 7.81, TDS value ranged from 207 to 380 $\mathrm{mg} / \mathrm{L}$, Turbidity values ranged from 0.281 to 1.942 (NTU), Color values were in the range from 19.23 to 21.8 (TCU), EC values were in the range of 464 to $990 \mu \mathrm{S} / \mathrm{cm}$, results were within the WHO and EPA standard limits. DO values were ranged from 2.8 to $4.4 \mathrm{mg} / \mathrm{L}$. EC values of RW5 $(1827 \mu \mathrm{S} / \mathrm{cm})$ and DO values of RW3 (5.6 mg/L) and RW $5(5.1 \mathrm{mg} / \mathrm{L})$. The standard value of WHO for EC is 1000, DO value of Who and EPA is 5 , so these values were above the WHO and EPA limits, the values of other physiochemical parameters satisfied the WHO and EPA standard values (Table 2).

Table 2. Physico-chemical parameters river water (surface water)

\begin{tabular}{|l|l|l|l|l|l|l|l|}
\hline S.no & Samples & PH & EC $\boldsymbol{\mu S} / \mathbf{c m}$ & DO $\mathbf{~ m g / l}$ & TDS mg/l & Turbidity NTU & Colour TCU \\
\hline EPA & & $6.5-8.5$ & - & 5 & $<1000$ & $<5$ & $5-50$ \\
\hline WHO & & $6.5-8.5$ & 1000 & 5 & $<1000$ & $<5$ & $5-25$ \\
\hline 1 & RW1 & 7.31 & 634 & 3.6 & 290 & 1.338 & 20.77 \\
\hline 2 & RW2 & 7.36 & 579 & 4.4 & 254 & 1.659 & 21.02 \\
\hline 3 & RW3 & 7.65 & 801 & 5.6 & 368 & 1.449 & 19.67 \\
\hline 4 & RW4 & 7.64 & 464 & 2.9 & 207 & 1.942 & 44.23 \\
\hline 5 & RW5 & 7.80 & 1827 & 5.1 & 317 & 0.580 & 19.32 \\
\hline 6 & RW6 & 7.72 & 708 & 3.5 & 340 & 0.281 & 20.11 \\
\hline 7 & RW7 & 7.69 & 650 & 3.5 & 279 & 1.506 & 21.71 \\
\hline 8 & RW8 & 7.81 & 732 & 4.3 & 320 & 1.473 & 21.8 \\
\hline 9 & RW9 & 7.45 & 843 & 3.8 & 380 & 0.310 & 20.23 \\
\hline 10 & RW10 & 7.75 & 990 & 2.8 & 284 & 0.289 & 20.9 \\
\hline
\end{tabular}

$\mathrm{EC}=$ Electro conductivity, DO Dissolved oxygen, TDS Total dissolved solids 


\section{Well water}

The $\mathrm{pH}$ values were ranged from 8.01 to 8.44 which were within the recommended limits of WHO, except WW1 (8.52), WW2 (8.61) and WW 3 (8.58) were greater than the standard limits of WHO and EPA. The EC values were in the range of 466 to 917 $\mu \mathrm{S} / \mathrm{cm}$. EC value of WW4 (1013) and WW6 (1774) were greater than the limits. DO values were in the range of $1.4 \mathrm{mg} / \mathrm{L}$ to 5 $\mathrm{mg} / \mathrm{L}$ and value of WW $4(5.1 \mathrm{mg} / \mathrm{L})$ were greater than the limits. TDS values were ranged from $225 \mathrm{mg} / \mathrm{L}$ to $860 \mathrm{mg} / \mathrm{L}$. Turbidity values were in the range from 0.31 to 2.806 NTU. Color values were in the range from 22.2 to $23.75 \mathrm{TCU}$, the values obtained were within the WHO and EPA standard limits (Table 3).

Table 3. Physio-chemical parameter of well water

\begin{tabular}{|l|l|l|l|l|l|l|l|}
\hline S.no & Samples & PH & $\begin{array}{l}\text { Electro conductive } \\
\boldsymbol{\mu s} / \mathbf{c m}\end{array}$ & DO mg/l & TDS mg/l & $\begin{array}{l}\text { Turbidity } \\
\text { NTU }\end{array}$ & $\begin{array}{l}\text { Colour } \\
\text { TCU }\end{array}$ \\
\hline \multicolumn{2}{|l|}{ azEPA } & $6.5-8.5$ & - & 5 & $<1000$ & $<5$ & $\leq 5$ \\
\hline WHO & $6.5-8.5$ & 1000 & 5 & $<1000$ & $<5$ & $\leq 5$ \\
\hline 1. & WW1 & 8.52 & 466 & 4.7 & 225 & 1.26 & 22.2 \\
\hline 2. & WW2 & 8.61 & 693 & 4.0 & 333 & 1.20 & 22.31 \\
\hline 3. & WW3 & 8.58 & 702 & 4.6 & 336 & 3.94 & 22.45 \\
\hline 4. & WW4 & 8.44 & 1013 & 5.1 & 492 & 0.84 & 22.19 \\
\hline 5. & WW5 & 8.27 & 915 & 3.2 & 445 & 1.580 & 22.34 \\
\hline 6. & WW6 & 8.16 & 1774 & 5.0 & 860 & 2.531 & 22.19 \\
\hline 7. & WW7 & 8.28 & 740 & 3.1 & 332 & 1.506 & 22.16 \\
\hline 8. & WW8 & 8.27 & 842 & 3.3 & 335 & 2.806 & 23.75 \\
\hline 9. & WW9 & 8.01 & 603 & 1.4 & 267 & 0.31 & 22.5 \\
\hline 10. & WW10 & 8.18 & 616 & 2.7 & 279 & 0.87 & 22.23 \\
\hline
\end{tabular}

$\mathrm{EC}=$ Electro conductivity, DO Dissolved oxygen, TDS Total dissolved solids

\section{Concentration of heavy and trace metals River water (surface)}

The concentrations of trace elements i.e. $\mathrm{Zn}$ was in range from $0.012 \pm 0.001155$ to $0.099 \pm 0.000333 \mathrm{ppm}$. Fe concentration was in the range from $0.018 \pm 0.001155$ to $0.069 \pm 0.001155 \mathrm{ppm}$. Mn concentration was in the range from $0.068 \pm 0.029006$ to $0.44 \pm 0.12702 \mathrm{ppm}$. Cu concentration was in the range from $0.071 \pm 0.000577$ to 0.393 $\pm 0.2935 \mathrm{ppm}$. The result showed that all the trace metals in river (surface) water were below permissible limits set by WHO [16] and EPA [17]. The concentration of $\mathrm{Cd}$ was in the range from $0.085 \pm 0.00057735$ to $0.644 \pm 0.276241$ and concentration of $\mathrm{Pb}$ was in the range from $1.555 \pm 0.064086$ to $2.059 \pm 0.004055$. The results showed that the concentration of $\mathrm{Cd}$ and $\mathrm{Pb}$ in drinking water samples exceeded the WHO and EPA safe limits. $\mathrm{Cr}$ and $\mathrm{Ni}$ were not detected in any samples (Table 4). 
Table 4. Concentration of heavy metals and trace metals in river (Surface) water

\begin{tabular}{|c|c|c|c|c|c|c|c|c|}
\hline Metals & Cd & $\mathbf{Z n}$ & $\mathrm{Fe}$ & Mn & $\mathbf{C u}$ & $\mathrm{Cr}$ & $\mathbf{N i}$ & $\mathbf{P b}$ \\
\hline $\begin{array}{l}\text { RW } 1 \\
(\mathrm{ppm} \pm \mathrm{SEM})\end{array}$ & $\begin{array}{l}0.085 \pm \\
0.00057735\end{array}$ & $\begin{array}{l}0.087 \pm \\
0.001155\end{array}$ & $\begin{array}{l}0.069 \pm \\
0.001155\end{array}$ & $\begin{array}{l}0.101 \pm \\
0.001155\end{array}$ & $\begin{array}{l}0.393 \pm \\
0.2935\end{array}$ & ND & ND & $\begin{array}{l}1.555 \pm \\
0.064086\end{array}$ \\
\hline $\begin{array}{l}\text { RW } 2 \\
(\mathrm{ppm}+\mathrm{SEM})\end{array}$ & $\begin{array}{l}0.087 \pm \\
0.001155\end{array}$ & $\begin{array}{l}0.083 \pm \\
0.001735\end{array}$ & $\begin{array}{l}0.042 \pm \\
0.001155\end{array}$ & $\begin{array}{l}0.097 \pm \\
0.001732\end{array}$ & $\begin{array}{l}0.08 \pm \\
0.005775\end{array}$ & ND & ND & $\begin{array}{l}1.741 \pm \\
0.000577\end{array}$ \\
\hline $\begin{array}{l}\text { RW } 3 \\
(\mathrm{ppm} \pm \mathrm{SEM})\end{array}$ & $\begin{array}{l}0.644 \pm \\
0.276241\end{array}$ & $\begin{array}{l}0.012 \pm \\
0.001155\end{array}$ & $\begin{array}{l}0.015 \pm \\
0.001732\end{array}$ & $\begin{array}{l}0.101 \pm \\
0.000577\end{array}$ & $\begin{array}{l}0.087 \pm \\
0.00333\end{array}$ & ND & ND & $\begin{array}{l}1.621 \pm \\
0.000577\end{array}$ \\
\hline $\begin{array}{l}\text { RW } 4 \\
(\mathrm{ppm}+\mathrm{SEM})\end{array}$ & $\begin{array}{l}0.104 \pm \\
0.0005773\end{array}$ & $\begin{array}{l}0.058 \pm \\
0.001155\end{array}$ & $\begin{array}{l}0.018 \pm \\
0.001155\end{array}$ & $\begin{array}{l}0.44 \pm \\
0.12702\end{array}$ & $\begin{array}{l}0.073 \pm \\
0.000577\end{array}$ & ND & ND & $\begin{array}{l}1.964 \pm \\
0.001155\end{array}$ \\
\hline $\begin{array}{l}\text { RW } 5 \\
(\mathrm{ppm} \pm \mathrm{SEM})\end{array}$ & $\begin{array}{l}0.105 \pm \\
0.001155\end{array}$ & $\begin{array}{l}0.061 \pm \\
0.000577\end{array}$ & $\begin{array}{l}0.016 \pm \\
0.001155 \\
\end{array}$ & $\begin{array}{l}0.093 \pm \\
0.001155\end{array}$ & $\begin{array}{l}0.071 \pm \\
0.000577\end{array}$ & ND & ND & \begin{tabular}{|l}
$1.726 \pm$ \\
0.001155 \\
\end{tabular} \\
\hline $\begin{array}{l}\text { RW } 6 \\
(\mathrm{ppm}+\mathrm{SEM})\end{array}$ & $\begin{array}{l}0.11 \pm \\
0.011547\end{array}$ & $\begin{array}{l}0.013 \pm \\
0.001155\end{array}$ & $\begin{array}{l}0.019 \pm \\
0.001155\end{array}$ & $\begin{array}{l}0.069 \pm \\
0.029501\end{array}$ & $\begin{array}{l}0.078 \pm \\
0.000577\end{array}$ & ND & ND & $\begin{array}{l}1.759 \pm \\
0.000577\end{array}$ \\
\hline $\begin{array}{l}\text { RW } 7 \\
(\mathrm{ppm}+\mathrm{SEM})\end{array}$ & $\begin{array}{l}0.105 \pm \\
0.001155\end{array}$ & $\begin{array}{l}0.017 \pm \\
0.000577\end{array}$ & $\begin{array}{l}0.018 \pm \\
0.000577\end{array}$ & $\begin{array}{l}0.098 \pm \\
0.000577\end{array}$ & $\begin{array}{l}0.071 \pm \\
0.000577\end{array}$ & ND & ND & $\begin{array}{l}1.992 \pm \\
0.000577 \\
\end{array}$ \\
\hline $\begin{array}{l}\text { RW } 8 \\
(\mathrm{ppm} \pm \mathrm{SEM})\end{array}$ & $\begin{array}{l}0.103 \pm \\
0.001155\end{array}$ & $\begin{array}{l}0.306 \pm \\
0.297001 \\
\end{array}$ & $\begin{array}{l}0.034 \pm \\
0.006667\end{array}$ & $\begin{array}{l}0.11 \pm \\
0.000333\end{array}$ & $\begin{array}{l}0.077 \pm \\
0.000577\end{array}$ & ND & ND & $\begin{array}{l}2.059 \pm \\
0.004055 \\
\end{array}$ \\
\hline $\begin{array}{l}\text { RW } 9 \\
(\mathrm{ppm}+\mathrm{SEM})\end{array}$ & $\begin{array}{l}0.098 \pm \\
0.001155\end{array}$ & $\begin{array}{l}0.034 \pm \\
0.000577\end{array}$ & $\begin{array}{l}0.022 \pm \\
0.006351\end{array}$ & $\begin{array}{l}0.068 \pm \\
0.029006\end{array}$ & $\begin{array}{l}0.098 \pm \\
0.000577\end{array}$ & ND & ND & $\begin{array}{l}1.708 \pm \\
0.002\end{array}$ \\
\hline $\begin{array}{l}\mathrm{RW} 10 \\
(\mathrm{ppm} \pm \mathrm{SEM})\end{array}$ & $\begin{array}{l}0.102 \pm \\
0.000333 \\
\end{array}$ & $\begin{array}{l}0.099 \pm \\
0.000333\end{array}$ & $\begin{array}{l}0.045 \pm \\
0.000333\end{array}$ & $\begin{array}{l}0.105 \pm \\
0.000333\end{array}$ & $\begin{array}{l}0.095 \pm \\
0.003333\end{array}$ & ND & ND & $\begin{array}{l}1.988 \pm \\
0.000667 \\
\end{array}$ \\
\hline $\begin{array}{l}\text { WHO limits } \\
(\mathrm{ppm})\end{array}$ & 0.003 & 3 & 0.3 & 0.5 & 1 & 0.05 & 0.02 & 0.01 \\
\hline $\begin{array}{l}\text { EPA limits } \\
(\mathrm{ppm})\end{array}$ & 0.01 & 5 & 0.3 & $<0.5$ & 1 & $<0.05$ & 0.02 & $<0.05$ \\
\hline
\end{tabular}

Values are Mean \pm SEM of the concentration of heavy metals in river water

\section{Well water}

Concentration of trace elements i.e. $\mathrm{Zn}$ ranged from $0.014 \pm 0.001155$ to $0.068 \pm$ $0.000333 \mathrm{ppm}$. Fe concentration was in the range from $0.022 \pm 0.006351$ to $0.129 \pm$ $0.020502 \mathrm{ppm}$. Mn concentration was in the range from $0.085 \pm 0.000577$ to $0.101 \pm$ $0.000577 \mathrm{ppm} . \mathrm{Cu}$ concentration was in the range from $0.049 \pm 0.000577$ to $0.078 \pm$ $0.000882 \mathrm{ppm}$. The result showed that all these trace metals in well water were below the permissible limits set by WHO [16] and
EPA [17]. The concentration of $\mathrm{Cu}$ in WW7 $(0.958 \pm 0.002404)$ and WW9 (0.941 \pm 0.000577 ) samples were within the allowed limits of WHO and EPA (1 ppm). The concentration of $\mathrm{Cd}$ was in the range from $0.109 \pm 0.000577$ to $0.199 \pm 0.000577$. The concentration of $\mathrm{Pb}$ was in the range of $0.882 \pm 0.000577$ to $1.364 \pm 0.000577$. The results showed that the concentrations of $\mathrm{Cd}$ and $\mathrm{Pb}$ were above the WHO and EPA safe limits. $\mathrm{Cr}$ and $\mathrm{Ni}$ were not detected in any samples (Table 5). 
Table 5. Concentration of heavy metals and trace metals detected in well water

\begin{tabular}{|c|c|c|c|c|c|c|c|c|}
\hline Metals & Cd & $\mathbf{Z n}$ & $\mathbf{F e}$ & Mn & $\mathbf{C u}$ & $\mathrm{Cr}$ & $\mathbf{N i}$ & $\mathbf{P b}$ \\
\hline $\begin{array}{l}\text { WW } 1 \\
(\mathrm{ppm}+\mathrm{SEM})\end{array}$ & $\begin{array}{l}0.109 \pm \\
0.000577\end{array}$ & $\begin{array}{l}0.045 \pm \\
0.000577\end{array}$ & $\begin{array}{l}0.069 \pm \\
0.000577\end{array}$ & $\begin{array}{l}0.088 \pm \\
0.006351\end{array}$ & $\begin{array}{l}0.073 \pm \\
0.000577\end{array}$ & ND & ND & $\begin{array}{l}0.882 \pm \\
0.000577\end{array}$ \\
\hline $\begin{array}{l}\text { WW } 2 \\
(\mathrm{ppm}+\mathrm{SEM})\end{array}$ & $\begin{array}{l}0.111 \pm \\
0.000577\end{array}$ & $\begin{array}{l}0.0307 \pm \\
0.000333\end{array}$ & $\begin{array}{l}0.071 \pm \\
0.000577\end{array}$ & $\begin{array}{l}0.091 \pm \\
0.000577\end{array}$ & $\begin{array}{l}0.067 \pm \\
0.000577\end{array}$ & ND & ND & $\begin{array}{l}0.873 \pm \\
0.001732\end{array}$ \\
\hline $\begin{array}{l}\text { WW } 3 \\
(\mathrm{ppm}+\mathrm{SEM})\end{array}$ & $\begin{array}{l}0.117 \pm \\
0.000577\end{array}$ & $\begin{array}{l}0.068 \pm \\
0.000333\end{array}$ & $\begin{array}{l}0.129 \pm \\
0.020502\end{array}$ & $\begin{array}{l}0.099 \pm \\
0.000577\end{array}$ & $\begin{array}{l}0.073 \pm \\
0.000577\end{array}$ & ND & ND & $\begin{array}{l}1.017 \pm \\
0.000577\end{array}$ \\
\hline $\begin{array}{l}\text { WW } 4 \\
(\mathrm{ppm} \pm \mathrm{SEM})\end{array}$ & $\begin{array}{l}0.115+ \\
0.000577\end{array}$ & $\begin{array}{l}0.038+ \\
0.000577\end{array}$ & $\begin{array}{l}0.048 \pm \\
0.000577\end{array}$ & $\begin{array}{l}0.101 \pm \\
0.000577\end{array}$ & $\begin{array}{l}0.054+ \\
0.000577\end{array}$ & ND & ND & $\begin{array}{l}1.104+ \\
0.000577\end{array}$ \\
\hline $\begin{array}{l}\text { WW } 5 \\
(\mathrm{ppm} \pm \mathrm{SEM})\end{array}$ & $\begin{array}{l}0.121 \pm \\
0.000577\end{array}$ & $\begin{array}{l}0.014 \pm \\
0.001155\end{array}$ & $\begin{array}{l}0.065 \pm \\
0.000577\end{array}$ & $\begin{array}{l}0.095 \pm \\
0.000577\end{array}$ & $\begin{array}{l}0.055 \pm \\
0.00577\end{array}$ & ND & ND & $\begin{array}{l}1.11 \pm \\
0.005774\end{array}$ \\
\hline $\begin{array}{l}\text { WW } 6 \\
(\mathrm{ppm} \pm \mathrm{SEM})\end{array}$ & $\begin{array}{l}0.127 \pm \\
0.000577\end{array}$ & $\begin{array}{l}0.014 \pm \\
0.000577\end{array}$ & $\begin{array}{l}0.058 \pm \\
0.000577\end{array}$ & $\begin{array}{l}0.085 \pm \\
0.000577\end{array}$ & $\begin{array}{l}0.049 \pm \\
0.000577\end{array}$ & ND & ND & $\begin{array}{l}1.239 \pm \\
0.032835\end{array}$ \\
\hline $\begin{array}{l}\text { WW } 7 \\
(\mathrm{ppm}+\mathrm{SEM})\end{array}$ & $\begin{array}{l}0.121 \pm \\
0.000577\end{array}$ & $\begin{array}{l}0.045 \pm \\
0.00882\end{array}$ & $\begin{array}{l}0.055 \pm \\
0.000577\end{array}$ & $\begin{array}{l}0.091 \pm \\
0.000577\end{array}$ & $\begin{array}{l}0.958 \pm \\
0.002404\end{array}$ & ND & ND & $\begin{array}{l}1.17 \pm \\
0.00577\end{array}$ \\
\hline $\begin{array}{l}\text { WW } 8 \\
(\mathrm{ppm} \pm \text { SEM })\end{array}$ & $\begin{array}{l}0.122 \pm \\
0.000333\end{array}$ & $\begin{array}{l}0.039 \pm \\
0.016586\end{array}$ & $\begin{array}{l}0.022 \pm \\
0.006351\end{array}$ & $\begin{array}{l}0.093 \pm \\
0.000577\end{array}$ & $\begin{array}{l}0.055 \pm \\
0.000882\end{array}$ & ND & ND & $\begin{array}{l}1.356 \pm \\
0.000577\end{array}$ \\
\hline $\begin{array}{l}\text { WW } 9 \\
(\mathrm{ppm} \pm \mathrm{SEM})\end{array}$ & $\begin{array}{l}0.199 \pm \\
0.000577\end{array}$ & $\begin{array}{l}0.05 \pm \\
0.005774\end{array}$ & $\begin{array}{l}0.105 \pm \\
0.000577\end{array}$ & $\begin{array}{l}0.103 \pm \\
0.000577\end{array}$ & $\begin{array}{l}0.941 \pm \\
0.000577\end{array}$ & ND & ND & $\begin{array}{l}1.165 \pm \\
0.001155\end{array}$ \\
\hline $\begin{array}{l}\text { WW } 10 \\
(\mathrm{ppm} \pm \text { SEM) }\end{array}$ & $\begin{array}{l}0.128 \pm \\
0.00057735\end{array}$ & $\begin{array}{l}0.049 \pm \\
0.000577\end{array}$ & $\begin{array}{l}0.095 \pm \\
0.000577\end{array}$ & $\begin{array}{l}0.095 \pm \\
0.000577\end{array}$ & $\begin{array}{l}0.078 \pm \\
0.000882\end{array}$ & ND & ND & $\begin{array}{l}1.364 \pm \\
0.000577\end{array}$ \\
\hline $\begin{array}{l}\text { WHO } \\
\text { limits(ppm) }\end{array}$ & 0.003 & 3 & 0.3 & 0.5 & 1 & 0.05 & 0.02 & 0.01 \\
\hline EPA limits(ppm) & 0.01 & 5 & 0.3 & $<0.5$ & 1 & $<0.05$ & 0.02 & $<0.05$ \\
\hline
\end{tabular}

Values are Mean \pm SEM of the concentration of heavy metals in well water

\section{Disscusion}

In current study the water samples were selected from district Jhal Magsi, Balochistan, as previously no data was available on the subject. People in this area only rely on River and Well water for drinking and agriculture purpose. Twenty (20) samples were collected (10 from river water and 10 from Well water) from different sites. Six metals ( $\mathrm{Zn}, \mathrm{Fe}, \mathrm{Mn}, \mathrm{Cu}$, $\mathrm{Cd}$ and $\mathrm{Pb}$ ) were found in all water samples analyzed. $\mathrm{Ni}$ and $\mathrm{Cr}$ were not detected in any samples. Mean concentrations of lead and cadmium in all the samples were significantly greater than Permissible limits of WHO and EPA.

Concentration of $\mathrm{Zn}$ was below the permissible limits of WHO and EPA. Zinc is an important trace metal found in living organisms. The significance of zinc for the human diet was discovered in 1962 [18].
Zinc plays a significant role in the synthesis of protein. Low concentration of $\mathrm{Zn}$ may result in increased secretion, genetic disorders, nutritional deficiency, and reduced absorption [19]. Zn deficiency also causes diminishing of reproduction and growth [20].

Concentration of $\mathrm{Fe}$ was also below the permissible limits set by WHO and EPA. Fe is a vital element in human diet. Estimates of the minimum daily requirement for $\mathrm{Fe}$ depend on sex, physiological status, age, $\mathrm{Fe}$ bioavailability and it ranges from about 10 $50 \mathrm{mg} /$ day [21]. The continued consumption of drinking water with great concentration of $\mathrm{Fe}$ may lead to a liver disease called haermosiderosis and the lack of Fe causes a disease called anemia [22].

Concentration of copper was also below the permissible limits of WHO and EPA. Deficiency of $\mathrm{Cu}$ consumption causes 
growth inhibition, blood circulation difficulties and anemia [23]. $\mathrm{Cu}$ is important substance for human life, but prolonged exposure to pollutant drinking water with $\mathrm{Cu}$ can result in anemia, kidney and liver disease $[24,25]$.

$\mathrm{Mn}$ is also an important component of some enzymes that are required for the fat, protein and carbohydrate metabolism. For some animals, the lethal dosage is relatively low. $\mathrm{Mn}$ complexes can cause failure in development of animal fetuses, brain damage, vascular disturbances, declines in blood pressure, and liver and lung disease [26]. Results of current study reveal that the trace elements in drinking (River and Well) water were below the permissible limits. Use of these waters may lead to disorders due to deficiency of trace metals. Government and other organizations are required to make measures and provide drinking water with sufficient amount of trace metals to prevent the diseases.

Lead and Cadmium concentration were above the permissible limits of WHO and EPA. Chronic contact to heavy metals such as $\mathrm{Cd}$ and $\mathrm{Pb}$ can result in lethal health hazards in human beings [27]. These heavy metals have very long biotic half-lives, which shows their ability to accumulate in different organs of the body and consequently results in irritating side effects [28-30].

There are some other studies which link $\mathrm{Pb}$ exposures even at small quantity with an increase in blood pressure [31] as well as with reduction in the intelligence of children [32] and with responsiveness disorders [33]. Cadmium and its complexes are carcinogenic for human health and are classified as $1^{\text {st }}$ group by International Agency for Research on Cancer, as their positive associations have been observed for cancers of the kidney and of the prostate and cause cancer of the lungs [34]. Cadmium intoxication can also play a central role for pulmonary and kidney damages, and skeletal muscle damage $[35,36]$. $\mathrm{Cd}$ is extremely toxic and responsible for numerous types of food toxicities. Lesser amount of cadmium can cause adverse changes in the blood vessels of human kidney. Cd have the ability to replace zinc biochemically and causes kidney damage and increase in the blood pressures [22].

Cadmium $(\mathrm{Cd})$ is an element of great concern from the point of toxicity and its introduction can cause both acute and chronic health diseases in living creatures. Cadmium occurs naturally in ocean water and in the earth's layer. Cd impedes with enzymes and causes a painful disease called Itai-itai [35]. In current study concentration of $\mathrm{Pb}$ and $\mathrm{Cd}$ were above the permissible limits, it may results in sever health problems. Therefore it is suggested that water should pretreated, and purification plants must be utilized to save the life of the people.

\section{Conclusion}

It is concluded that the trace metals were below the permissible limits, whereas heavy metals i.e. $\mathrm{Pb}$ and $\mathrm{Cd}$ were above the standard limits of WHO and EPA. Therefore, the use of polluted water with these metals may result in sever health problems.

\section{Authors' contributions}

Conceived and designed the experiments: S Mustafa \& N Baloch, Performed the experiments: S Mustafa \& S Muhammad, Analyzed the data: Y Malik, T Khan \& M Bibi, Contributed reagents/ materials/ analysis tools: A Qadir \& G Razaque, Wrote the paper: S Mustafa \& I A Baloch.

\section{References}

1.Hussain J, Shah J, Khan I, Lopes DA, Souza RS, Silva JDS, Junior EPQ \& Nascismato IO (2012) Determination of trace elements in the drinking water of mardan district KPK Pakistan. EurasiaJ Agre \& Environ Sci 12(8): 1091-1094. 
2.Ezemonye LIN \& Enuneku A (2005). Evaluationof acute toxicity of Cadmium and Lead to Amphibian Tadpole (Toad: Bufomaculates and Frog: Ptychadenabibroni). J Aqua Sci 20(1): $33-36$

3.Kar D, Sur P, Mandal SK, Saha T \& Kole RK (2008). Assessment of heavy metal pollution insurface water. Int $J$ Environ Sci Tech 5(1):119-124.

4.Nair IV, Singh K, Arumugam M, Gangadhar K \& Clarson D (2010). Trace metal quality of Meenachil River at Kottayam, Kerala (India) by principal component analysis. World Appl Sci J 9(10): 1100-1107.

5.Bilal S \& Rahman S (2015). Determination of Some Heavy Metals in Water Collected From River Chublat (Hassan Abdal) Pakistan. Int J Sci Res 4(2): 1894-1897.

6.Ahmad M, Muhammed S, Mehjabeen, Jahan N, Jan SU \& Qureshi ZU (2014). Anti-dermatitis, anxiolytic and analgesic effects of Rhazya stricta from Balochistan. Pak J Pharm Sci 27(3): 481-486

7.Ahmad S (2007). Restructuring national agricultural research system (NARS)the case of NARS Balochistan (NARSB). Water for Balochistan: Policy Briefings 3(7).

8.UNICEF, District Development profile (2011). Jhal Magsi Planning \& Development Department, Government of Balochistan in Collaboration with UNICEF page 1-25.

9.Al-Musharafi SK, Mahmoud IY \& AlBahry SN (2014). Environmental contamination by industrial effluents and sludge relative to heavy metals. $J$ Geosci Environ Prot 2(02): 14.

10. Joshi DM, Kumar A \& Agrawal N (2009). Studies on physicochemical parameters to assess the water quality of river Ganga for drinking purpose in
Haridwar district. Ras J Chem 2: 195203.

11. Fong SS, Kanakaraju D \& Ling SC (2006). Evaluation of the acid digestion method with different solvent combination for the determination of Iron, Zinc and Lead in canned sardines. Malayan J Chem 8 (1): $10-15$.

12. Adnan MM (2003). Determination of Cadmium and Lead in different cigarette brands in Jordan. Environ Monit Assess 104: 163-170.

13. Alzrog AM, Mohamed AS, Zakaria RB \& Alias AK (2013). Effect of planting media (rice husk and coco peat) on the uptake of cadmium and some micronutrients in chilli (capsicum annum 1.). Pure Appl Bio 2(3):76.

14. Khan MJ, Achakzai AK, Iqbal Y, Ullah W, Khan N, Sharif M, Afzal M, Bazai ZA \& Ullah F (2015). Heavy metals status of the urban and agricultural soils of Peshawar, Pakistan. Pure Appl Bio 4(3):418.

15. Sultana S, Sultana T \& Jabeen F (2015) Accumulation of heavy metals $(\mathrm{Cu}$, $\mathrm{Zn}, \mathrm{Ni}, \mathrm{Cd}, \mathrm{Co}, \mathrm{Pb}$ and $\mathrm{Cr}$ ) in blood of freshwater turtles from Balloki headworks and Trimmu barrage, Punjab, Pakistan. Pure Appl Bio 4(3): 280.

16. World Health Organization (WHO) (2011). Guidelines for Drinking-Water Quality, WHO Press, Geneva, Switzerland, 4th edition.

17. Pak- EPA (2007) Ambient Air and Water Quality Investigation in Quetta. Available at. http://www.environment.gov.pk

18. Khan TA (2011). Trace elements in the drinking water and their possible health effects in Aligarh City India. $J$ Water Reso Prot 3(7): 522.

19. Colak H, Soylak M \& Turkoglu O (2005). Determination of trace metal 
content of various herbal and fruit teas produced and marketed in Turkey. Trace Elements \& Electrolytes 22(3).

20. Rattan RK, Datta SP, Chhonkar PK, Suribabu K \& Singh AK (2005). Longterm impact of irrigation with sewage effluents on heavy metal content in soils, crops and groundwater-a case study. Agri Ecos Environ 109(3): 310322.

21. World Health Organization. Guidelines for drinking-water quality: recommendations. Vol. 1. World Health Organization, 2004.

22. Rajappa B, Manjappa S \& Puttaiah ET (2010). Monitoring of heavy metal concentration in groundwater of Hakinaka Taluk. India Cont Engn Sci 3(4): 183-190.

23. Jennings G D Sneed RE \& Clair MB (1996). Metals in drinking water. Nor Carolina Coop Extens Ser AG-473-1.

24. Madsen H, Poulsen L \& Grandjean P (1990). Risk of high copper content in drinking water. Ugeskrift for laeger 152(25): 1806-1809.

25. Bent S \& Böhm K (1995). Copperinduced liver cirrhosis in a 13-month old boy. Gesundheitswesen (Bundesverband der Arzte des Offentlichen Gesundheitsdienstes (Germany) 57(10): 667-669.

26. Stokinger HE (1981). The metals. Patty's industrial hygie. Toxico 2: 1749-1769.

27. O'Reilly CA, Chatman J \& Caldwell DF (1991). People and organizational culture: A profile comparison approach to assessing personorganization fit. Aca Manag J 34(3): 487-516.

28. Järup L (2003). Hazards of heavy metal contamination. $\mathrm{Br}$ Med Bull 68(1): 167-182.
29. Sathawara NG, Parikh DJ \& Agarwal, YK (2004). Essential heavy metals in environmental samples from western India. Bull Environ Contam Toxicol 73(4): 756-761.

30. Yavuz B, Ertugrul DT, Cil H, Ata N, Akin KO, Yalcin AA \& Tutal E (2009). Increased levels of 25 hydroxyvitamin D and 1, 25dihydroxyvitamin $\mathrm{D}$ after rosuvastatin treatment: a novel pleiotropic effect of statins? Cardiovascular drugs and therapy 23(4): 295-299.

31. Zietz BP, Lap J \& Suchenwirth R (2007). Assessment and management of tap water Lead contamination in Lower Saxon, Germany. Int J Environ Health Res 17(6): 407-418.

32. Needleman HL (1992). The current status of childhood low-level lead toxicity. Neurotoxicology 14(2-3): 161-166.

33. Yule W \& Rutter M (1985). Effect of lead on children's behavior and cognitive performance: a critical review. Diet Environ lead human health effects 2 .

34. Godt J, Scheidig F, Grosse-Siestrup C, Esche V, Brandenburg P, Reich A \& Groneberg DA (2006). The toxicity of cadmium and resulting hazards for human health. $J$ occupational med toxi 1(1): 1 .

35. Waseem A, Arshad J, Iqbal F, Sajjad A, Mehmood Z \& Murtaza G (2014). Pollution status of Pakistan: a retrospective review on heavy metal contamination of water, soil, and vegetables. Bio Med res int 2014.

36. Nordberg G, Jin T, Bernard A, Fierens S, Buchet JP, Ye T \& Wang H (2002). Low bone density and renal dysfunction following environmental cadmium exposure in China. AMBIO. J Human Environ 31(6): 478-481. 